\title{
Lessons Learned from the Srebrenica Massacre: From UN Peacekeeping Reform to Legal Responsibility
}

\author{
Cedric Ryngaert ${ }^{1} \cdot$ Nico Schrijver $^{2}$
}

(c) The Author(s) 2015. This article is published with open access at Springerlink.com

\begin{abstract}
This article introduces the special issue on Srebrenica by reflecting on how the fall of Srebrenica has served as a trigger for proposals to fundamentally transform international law, especially the law relating to international crimes, responsibility, and legal remedies for victims. It also assesses the efforts to reform UN peacekeeping in the wake of Srebrenica, including issues relating to mission creep and to robust peacekeeping. Lastly, the article introduces the six other contributions to this special issue.
\end{abstract}

Keywords Srebrenica $\cdot$ UN peacekeeping $\cdot$ Genocide $\cdot$ International crimes $\cdot$ State responsibility $\cdot$ Responsibility international organisations $\cdot$ Access to justice for victims · United Nations

\section{Introduction}

Twenty years ago, in July 1995, in one of the worst massacres in Europe after the Second World War, Bosnian Serb militia under the command of General Ratko Mladić killed about 8000 Bosnian Muslim men and boys in the vicinity of the

\footnotetext{
Nico Schrijver

n.j.schrijver@law.leidenuniv.nl

Cedric Ryngaert

C.M.J.Ryngaert@uu.nl

1 Utrecht, The Netherlands

2 Leiden, The Netherlands
}

Members of the board of editors. Cedric Ryngaert and Nico Schrijver are Professors of Public International Law at Utrecht University and Leiden University, respectively. As far as Ryngaert is concerned: the research which resulted in this publication has been funded by the European Research Council under the Starting Grant Scheme (Proposal 336230 - UNIJURIS) and by the Dutch Organization for Scientific Research under the VIDI Scheme. 
Bosnian town of Srebrenica. Combined with the genocide in Rwanda in 1994, the massacre came to symbolize the failure of the international community to prevent or stop the most gruesome atrocities committed against civilians.

The Netherlands International Law Review has decided to devote a special issue to commemorate the event in Srebrenica. Our Review's interest in the matter is not accidental. The military battalion of the UN Protection Force (UNPROFOR) which was based near Srebrenica - and which arguably failed to prevent the massacrewas Dutch ('Dutchbat'). Srebrenica has haunted the Dutch political and military establishment ever since. ${ }^{1}$ In 2002, as a result of an explosive report written by the Netherlands Institute for War Documentation, ${ }^{2}$ the Dutch Government even stepped down, with the Prime Minister acknowledging a modicum of responsibility, although not culpability, for Dutchbat's failures. Subsequently, victims initiated legal proceedings before the Dutch courts against the Netherlands and the United Nations, some of which were still ongoing at the time of writing.

Our ambition is not to give an overview of the massacre itself or of the international/national responses to it. Rather, we want to reflect on how Srebrenica has served as the trigger for proposals to fundamentally transform international law, especially the law relating to international crimes, responsibility, and remedies for victims, and how it has affected the UN's institutional capacity to respond to atrocities.

\section{The Impact of the Srebrenica Massacre on International Law}

The Srebrenica massacre has had a major impact on various fields of international law.

Firstly, international criminal prosecutions brought against presumed individual offenders of the Srebrenica massacre, especially before the International Criminal Tribunal for the former Yugoslavia (ICTY), have fostered the development of the law of genocide, and of the modes of individual criminal responsibility, e.g., command responsibility, and aiding and abetting.

Secondly, the multitude of actors actively or passively involved in the massacre-the Bosnian Serb militia, the Serbian army, the United Nations, and the Netherlands-have (re)kindled the international community's interest in questions of allocating responsibility between organized actors. When could the responsibility of a state be engaged with respect to international wrongful acts committed by a non-state armed group with which the state has some relationship? Are wrongful acts committed by UN peacekeepers attributable to the UN, to the troop-contributing nation, or rather to both?

Thirdly, the massacre has spurred the quest for accountability avenues and practically available remedies against responsible parties. In respect of a substantial number of atrocities in the aftermath of Srebrenica, fact-finding and inquiry

\footnotetext{
1 See for example the book by former Dutch Defence Minister Voorhoeve (2015).

2 Nederlands Instituut voor Oorlogsdocumentatie (2002); NIOD Institute for War, Holocaust and Genocide Studies, Srebrenica: Reconstruction, background, consequences and analyses of the fall of a 'safe area', 10 April 2002. This report is available at http://www.srebrenica.nl. One of the principal conclusions of the report is that 'the Dutch had to keep the peace where there was no peace'.
} 
commissions were established, whose reports documented the extent of the devastation, and could serve as the trigger for criminal prosecutions. International criminal tribunals - including the International Criminal Court, the Statute of which was signed just 3 years after Srebrenica-and national courts assumed their responsibility to fight impunity and dispense justice for the gravest crimes against humankind. (National) civil courts opened their doors to victims of massacres, thereby raising the question of the relationship between human rights and private international law. International organizations, such as the UN, were no longer seen as just 'do-gooders', but as entities whose actions could adversely impact individuals' enjoyment of human rights; this re-characterization gave rise to a questioning of their immunities before domestic courts and to the need for accessible dispute-resolution mechanisms to provide justice to victims. ${ }^{3}$

Fourthly, the apparent failings of the UN forced the organization to overhaul its capacity to adequately respond to Srebrenica-like massacres. This fourth impact will be the subject of the next section. The impact on the first three fields, which in essence pertain to questions of accountability, will in some detail be addressed by the other contributions to this special issue.

\section{UN Peacekeeping Reform in the Wake of Srebrenica}

Srebrenica's most important impact on the United Nations was that the massacre served as a trigger for the development of the doctrine of a 'Responsibility to Protect' (R2P) incumbent on the international community to protect vulnerable populations against genocide, war crimes, ethnic cleansing and crimes against humanity. This R2P has entered both UN discourse and practice; in its peaceful and non-peaceful (military intervention) dimensions, it features prominently in the 2005 World Summit Outcome. ${ }^{4}$ The UN Secretary-General's report on 'Implementing the responsibility to protect' ${ }^{5}$ has subsequently animated discussions throughout the United Nations system. ${ }^{6}$ R2P has not just remained a theoretical discourse, however. The UN has notably acted thereon by establishing a Peacebuilding Commission, an intergovernmental advisory body at the heart of the UN system that supports peace efforts in countries emerging from conflict, ${ }^{7}$ and by giving Security Council

\footnotetext{
3 See on this Blokker and Schrijver (2014).

4 UN General Assembly Resolution 60/1, World Summit Outcome, UN Doc. A/RES/60/1 (24 October 2005), paras. 138-139.

5 UN General Assembly, Implementing the responsibility to protect, Report of the Secretary-General, UN Doc. A/63/677 (12 January 2009). See also the report Fulfilling our collective responsibility: International assistance and the Responsibility to Protect, Report of the Secretary-General, UN Doc. A/68/947 (September 2014).

6 Zyberi (2013), ch. 4-8, 16-17 (discussing the roles of the UN Security Council, the General Assembly, the Secretary-General, the Human Rights Council, the International Law Commission, the International Court of Justice, and the International Criminal Tribunals for the former Yugoslavia and Rwanda).

7 See United Nations Peacebuilding Commission. http://www.un.org/en/peacebuilding/. Accessed 13 February 2015. This commission was established by UN General Assembly Resolution 60/180, The Peacebuilding Commission, UN Doc. A/RES/60/180 (30 December 2005) and UN Security Council Resolution 1645, UN Doc. S/RES/1645 (20 December 2005).
} 
mandates to use military force to protect civilians against their own regime, e.g., in Libya and Côte d'Ivoire. ${ }^{8}$ However, so far the Security Council has failed to apply R2P to the situation in Syria. ${ }^{9}$

Most importantly, the UN has taken a critical look at its peacekeeping capacity in the light of its responsibility to protect vulnerable populations. Peacekeeping, although not provided for in the UN Charter, has become one of the mainstays of UN activity, ever since the 1956 Suez crisis, when the first mission was established. ${ }^{10}$ For the fiscal year 1 July 2014-30 June 2015, peacekeeping expenses amounted to close to 8.5 billion USD per year, ${ }^{11}$ by far the largest operational expenses of the UN. As we write, more than 100,000 peacekeepers are under arms in 16 theatres, led by the UN Department of Peacekeeping Operations. ${ }^{12}$

The peacekeeping operations in both Rwanda and Bosnia-Hercegovina have been received critically by the UN itself. ${ }^{13}$ After these failures, the peacekeeping missions stopped being just passive forces interposed between parties to a conflict; instead, almost all of them were endowed with a primary mandate to protect civilians. In particular the 2000 Brahimi report-a report that laid bare the inefficiencies of peacekeeping and called for more robust peacekeeping-has been instrumental in bringing about this shift. ${ }^{14}$ At the time of writing, a report by a HighLevel Panel that takes stock of UN peacekeeping reforms since the adoption of the Brahimi report, as well as of special political missions, had just been published. This report explored new landscapes in peacekeeping and conflict prevention, called for a

\footnotetext{
${ }^{8}$ UN Security Council Resolution 1973, UN Doc. S/RES/1973 (17 March 2011) and UN Security Council Resolution 1975, UN Doc. S/RES/1975 (30 March 2011).

9 In UN Security Council Resolution 2139 the Council hints at R2P by demanding that 'all parties take all appropriate steps to protect civilians, including members of ethnic, religious and confessional communities, and stresses that, in this regard, the primary responsibility to protect its population lies with the Syrian authorities', UN Doc. S/RES/2139 (22 February 2014), para. 9.

${ }^{10}$ UN General Assembly Resolution 1001 (ES-I), UN Doc. A/RES/1001 (7 November 1956), established UNEF.

11 See United Nations Peacekeeping, Financing peacekeeping. http://www.un.org/en/peacekeeping/ operations/financing.shtml. Accessed 15 July 2015; UN Doc. A/C.5/69/17.

12 See United Nations Peacekeeping, Current peacekeeping operations. http://www.un.org/en/ peacekeeping/operations/current.shtml. Accessed 15 July 2015 and United Nations Peacekeeping, Peacekeeping factsheet. http://www.un.org/en/peacekeeping/resources/statistics/factsheet.shtml. Accessed 15 July 2015.

13 See reports of the UN Secretary-General, The Fall of Srebrenica, UN Doc. A/54/549 (15 November 1999) and The independent inquiry into the actions of the United Nations during the 1994 genocide in Rwanda, UN Doc. S/1999/1257 (15 December 1999).

14 UN General Assembly, Identical letters dated 21 August 2000 from the Secretary-General to the President of the General Assembly and the President of the Security Council: report of the Panel on United Nations Peace Operations (the so-called Brahimi report), UN Doc. A/55/305-S/2000/809 (21 August 2000). See for leading UN documents adopted after the report: UN Department of Peacekeeping Operations and Department of Field Support (2009) A new partnership agenda: Charting a new horizon for UN peacekeeping. http://www.un.org/en/peacekeeping/documents/newhorizon.pdf. Accessed 13 February 2015; UN Department of Peacekeeping Operations and Department of Field Support (2010) The new horizon initiative: Progress report No. 1. http://www.un.org/en/peacekeeping/documents/ newhorizon_update01.pdf. Accessed 13 February 2015; UN Department of Peacekeeping Operations and Department of Field Support (2011) The new horizon initiative: Progress report No. 2. http://www. un.org/en/peacekeeping/documents/newhorizon_update02.pdf. Accessed 13 February 2015.
} 
focus on political solutions and for responsive and flexible peace operations (the collective term for both peacekeeping operations and special political missions), and proposed stronger partnerships with regional organizations and troop-contributing countries as well as field-focused and people-centred mandates. ${ }^{15} \mathrm{~A}$ key recommendation of the report relates to the protection of civilians, with the report stating that every peacekeeper-civilian, military, police-must do all they can when civilians are under imminent threat. The report highlights that political leverage and influence can be more powerful than military response, and that, to deliver on the protection of civilians, the current gap in many missions between resources and mandates needs to be addressed.

Also various intermediary reports have been quite critical of UN peacekeeping, although they also hailed its successes in devising specific strategies to protect civilians (notably by engaging in political work and deterring attacks through the provision of physical security on UN bases), as well as in establishing early-warning systems. ${ }^{16}$ The strongest criticism levelled at UN peacekeeping was that the chain of events to support the protection of civilians was broken. A 2014 report drawn up by the UN Office of Internal Oversight Services (OIOS) was particularly damning in this respect, accusing the UN and troop-contributing nations of failing civilians in need and thus of undermining the raison d'être of UN peacekeeping. ${ }^{17}$ Although most UN peacekeeping missions can currently use-lethal-force to protect civilians-so not only in self-defence, in practice it turns out that such force is hardly used: according to OIOS, only four missions have ever fired a warning shot, and only three missions have ever intended to use (but did not necessarily use) lethal force. ${ }^{18}$ OIOS may perhaps focus excessively on the use of force, thereby downplaying political solutions, ${ }^{19}$ but in order to prevent a scenario like Srebrenica, there is no denying that the use of lethal force will sometimes be necessary, as a last resort. It is most unfortunate, 20 years after Srebrenica, that troop-contributing nations still consider that the risks of using force and even of having boots on the

\footnotetext{
15 Report of High-Level Independent Panel on Peace Operations, chaired by former President of TimorLeste and Nobel Laureate José Ramos-Horta, 16 June 2015, forthcoming as official UN doc. See also http://www.un.org. Accessed 15 July 2015.

16 See notably a 2009 independent study jointly commissioned by the Department of Peacekeeping Operations and the Office for the Coordination of Humanitarian Affairs: V Holt, G Taylor and M Kelly (2009) Protecting civilians in the context of UN peacekeeping operations: Successes, setbacks and remaining challenges. https://docs.unocha.org/sites/dms/Documents/Protecting\%20Civilians\%20in\% 20the $\% 20$ Context $\% 20$ of $\% 20$ UN\%20Peacekeeping\%20Operations.pdf. Accessed 13 February 2015; UN General Assembly, Evaluation of the implementation and results of protection of civilians mandates in United Nations peacekeeping operations: Report of the Office of Internal Oversight Services, Peacekeeping missions with protection of civilians mandates focus on prevention and mitigation activities and force is almost never used to protect civilians under attack, UN Doc. A/68/787 (7 March 2014) ('OIOS report').

17 OIOS report (2014).

18 See OIOS report, para. 25.

19 Annex I of the OIOS report, Comments on the draft report received from the Department of Peacekeeping Operations and the Department of Field Support, para. 3 ("we are concerned that the approach of the report overemphasizes one element of military action and devalues the importance of political solutions and other aspects of the comprehensive approach peacekeeping operations take in implementing their protection mandate').
} 
ground are too high, that peacekeepers are not always following orders of the UN but rather of their own capitals, that non-compliance with UN orders is not reported, that hierarchical decision-making causes delays in reaction, that missions are weak and spread too thinly, that proper information-gathering fails, and that peacekeepers fear penalties for action rather than for inaction. ${ }^{20}$ In light of these problems, Srebrenica redux is not fanciful. To give just one example, in spite of the presence of a UN peacekeeping mission in South Sudan (UNMISS), in 2014 the newlyestablished state descended into a vicious civil war in the course of which abominable atrocities against civilians were committed-tens of thousands of civilians have reportedly been massacred $-{ }^{21}$ without UNMISS being able to intervene. $^{22}$

Some better news has come from the Democratic Republic of the Congo (DRC), however. Concerned about the continuing threat posed by ragtag armed groups in the lawless east of that country, in 2013, the UN Security Council gave the UN peacekeeping mission MONUSCO — the world's largest peacekeeping mission - the explicit mandate to establish an 'Intervention Brigade' to 'neutralize' such armed groups. ${ }^{23}$ MONUSCO could claim some initial success, defeating the rebels of M23, and was engaged in a major operation, alongside DRC forces, ${ }^{24}$ against the Democratic Forces for the Liberation of Rwanda (FDLR), an outfit with its roots in the Rwandan genocide. MONUSCO is the only UN peacekeeping mission that conducts offensive operations against armed groups threatening civilians. In this regard, the UN Security Council has been cautious not to make it a precedent for future peacekeeping operations: in the pertinent resolution, it stipulated that

\footnotetext{
20 These are indeed the deficiencies identified by OIOS.

21 See International Crisis Group, Crisis watch database - South Sudan. http://www.crisisgroup.org/en/ publication-type/crisiswatch/crisiswatch-database.aspx?CountryIDs=\%7B8B313EA2-534B-4421-B78C776E93632115\%7D. Accessed 13 February 2014.

22 Civilians were even killed during attacks on UN bases. See, e.g., BBC News, South Sudan conflict: Attack on UN base 'kills dozens', 17 April 2014. http://www.bbc.com/news/world-africa-27074635. Accessed 13 February 2015. The International Crisis Group accused UNMISS of lacking a strategic vision. See International Crisis Group (2015) Sudan and South Sudan's merging conflicts, Africa report no. 223, 29 January 2015. http://www.crisisgroup.org/ /media/Files/africa/horn-of-africa/south\% 20sudan/223-sudan-and-south-sudan-s-merging-conflicts.pdf. Accessed 13 February 2015.

23 UN Security Council Resolution 2098, UN Doc. S/RES/2098 (28 March 2013).

24 To prevent the UN from siding with (government) troops that are themselves a threat to civilians, the UN has adopted a Human Rights Due Diligence Policy on United Nations Support to non-United Nations Security Forces, see UN Secretary-General, Identical letters dated 25 February 2013 from the SecretaryGeneral addressed to the President of the General Assembly and to the President of the Security Council, UN Doc. A/67/775-S/2013/110 (5 March 2013). The UN Secretary-General had already advised member states of his decision to institute this policy by means of a note verbale dated 25 October 2011 . See for an assessment Aust (2014). The application of this policy has led to tensions between the UN and the DRC. For example, in January 2015, citing the policy, the UN demanded that the DRC remove from the joint UN-DRC offensive against the rebels in eastern DRC a general who featured on a UN Red List, being accused of 121 rights violations including summary executions and rape. The DRC rejected the UN's demands, calling them a violation of its sovereignty. See Bloomberg News (2015) Congo rejects UN stance on general in anti-rebel offensive, 5 February 2015. http://www.bloomberg.com/news/articles/ 2015-02-05/congo-rejects-un-stance-on-general-in-offensive-against-rebels. Accessed 13 February 2015. A failure on the part of the DRC to comply with the UN's directions may result in the UN taking part in the offensive, with dire consequences for the civilians whom this push is supposed to protect.
} 
MONUSCO's mandate was extended 'on an exceptional basis and without creating a precedent or any prejudice to the agreed principles of peacekeeping' ${ }^{25}$ Clearly, the Council is concerned about mission creep, with UN peacekeeping missions becoming embroiled in a total war, without any exit strategy. ${ }^{26}$ Still, it is arguable that only more vigorous peacekeeping mandates that allow UN troops to engage with armed groups will alleviate the plight of civilians. Such engagement-which technically amounts to engagement in an armed conflict-does not mean taking sides between warring parties, thus compromising the hallowed rule of impartiality in peacekeeping. In fact, it only implies taking the side of the most vulnerable: civilians being attacked, raped and killed by groups having no regard whatsoever for human dignity. To be sure, offensive UN operations are not the silver bullet; ultimately, national institutions should be established that can offer security to civilians. After all, the primary responsibility to protect their civilians rests with them. But in the absence of viable alternatives, the UN should not stand idly by.

As can be gleaned from the reports evaluating UN peacekeeping reforms, however, for more forceful peacekeeping to become entrenched, a change of mentality rather than a lofty mandate in a resolution is called for. Richer UN member states should open their purses for beefed-up peacekeeping missions, troopcontributing nations should place sufficient troops at the UN's disposal so as to protect civilians spread over vast conflict areas, ${ }^{27}$ and these troops should also be willing to use their weapons to eliminate actual threats against civilians. Otherwise, Srebrenica will be repeated over and over again-as has unfortunately happened.

\section{The Contents of the Special Issue}

The contributions to this special issue address, as a matter of course, only some selected topics, with a focus on developments in the law relating to international crimes, the law relating to international responsibility, and the law relating to remedies for victims.

Harmen van der Wilt explores how the massacre in Srebrenica has been represented in the case law of the ICTY and argues that the reality of Srebrenica has been distorted somewhat as a result of the idiosyncrasies of the concepts of individual criminal responsibility, especially the modes of liability (aiding and abetting, joint criminal enterprise, command responsibility). ${ }^{28} \mathrm{He}$ warns us to be cautious in interpreting the use of legal concepts as a direct reflection of reality. It is

\footnotetext{
25 UNSC Resolution 2098, para. 9.

26 See in this respect also UNSC Resolution 2098, para. 10 ('Decides that the Intervention Brigade will have a clear exit strategy and that the Council will consider the continued presence of the Intervention Brigade in light of its performance').

27 Compare The Economist (2015) Congo and Rwanda: A long-awaited push to destroy some of Africa's most notorious killers, 24 January 2015. http://www.economist.com/news/middle-east-and-africa/ 21640439-long-awaited-push-destroy-some-africas-most-notorious-killers-ever-again. Accessed 13 February 2015 (observing that ' $[\mathrm{t}] \mathrm{he} \mathrm{UN}$ will never have enough troops to secure the vast country [DRC]').

28 Van der Wilt (2015).
} 
therefore key to take the limitations of the courtroom into account when assessing the legacy of the ICTY with respect to Srebrenica.

Kimberley Trapp dissects the International Court of Justice's decision in the Bosnia Genocide case-which concerned the massacre in Srebrenica, and criticizes the Court's approach to state responsibility for not adequately reflecting the reality of state engagement with non-state armed groups. ${ }^{29}$ As is known, the Court held that the acts of the Bosnian Serb militia were not attributable to the State of Serbia, as the latter did not exercise effective control over these militia, while nevertheless holding Serbia responsible for failing to prevent the genocide. Trapp argues that this approach overlooks contemporary state engagement with armed groups, and instead advocates the development of a paradigm that holds states responsible when they actively and materially increase the risk that an international crime will be committed by an armed group.

Heike Krieger addresses the accountability gap in UN peacekeeping operations for serious human rights violations perpetrated by UN peacekeepers. ${ }^{30}$ She observes that aggrieved individuals face enormous difficulties in seeking redress from the UN, but notes at the same time that domestic courts may offer viable accountability options. She admits that such courts typically uphold the UN's immunity, but draws attention to evolutions in the case law that point to the attribution of acts of peacekeepers to, and thus the responsibility of troop-contributing states for rights violations. She concludes that above all, however, member states need to close the accountability gap at the level of the United Nations, by establishing appropriate institutional dispute-settlement mechanisms.

Paolo Palchetti develops Krieger's point that domestic courts can provide an appropriate forum to establish responsibility for violations committed within the framework of peace operations. ${ }^{31}$ In this respect, he discusses the 2014 judgment of the District Court of The Hague in the Mothers of Srebrenica case, which attributed the failure of Dutchbat to provide protection to Bosnian civilians in Srebrenica to the Dutch State, and held the latter responsible vis-à-vis the victims. Palchetti takes the view that the District Court went too far in attributing certain acts to the Dutch State, while not going far enough when (not) attributing other acts. He concludes, however, that Mothers of Srebrenica is an important precedent in that it bases attribution on effective control rather than legal status, and allows for the possibility of dual attribution to both the UN and the troop-contributing state. The matter is currently under review before a court of appeal.

Larissa van den Herik shifts the focus from judicial dispute settlements to inquiry commissions as a method of fact-finding and truth-finding, with special reference to the UN and Dutch inquiries into the Srebrenica massacre. ${ }^{32}$ She argues that, depending on the authority with which inquiry commissions and their findings are endowed, fact-finding inquiries can play a meaningful complementary role to judicial proceedings in establishing the facts and providing accountability. Most

\footnotetext{
29 Trapp (2015).

${ }^{30}$ Krieger (2015).

31 Palchetti (2015).

32 Van den Herik (2015).
} 
importantly, they can be instrumental in namely overcoming the limitations of international criminal law which reduces conflict to the behaviour of just a few individuals (see also the article by Van der Wilt).

Kirsten Schmalenbach, finally, discusses the jurisdictional immunity of the United Nations before domestic courts and certain limitations to this. ${ }^{33}$ Taking the Dutch Supreme Court's affirmation of the UN's immunity in the Mothers of Srebrenica case as her starting point, she warns that lifting the UN's immunity may undermine the UN's capacity to provide international peace and security. Instead, she sees more merit in political rather than legal solutions, and suggests that claims regarding rights violations by the UN are settled with the member state rather than directly with the aggrieved individual. She does not exclude, however, that a failure to provide any form of accountability may ultimately result in domestic courts rejecting the UN's immunity.

The articles collected in this special issue all represent contributions to a better understanding of the evolution of public international law in the aftermath of the Srebrenica massacre, and to identify progress, but also serious shortcomings. Furthermore, they provide recommendations in order to better equip the international legal order to respond to, if not prevent, such horrifying acts.

Open Access This article is distributed under the terms of the Creative Commons Attribution 4.0 International License (http://creativecommons.org/licenses/by/4.0/), which permits unrestricted use, distribution, and reproduction in any medium, provided you give appropriate credit to the original author(s) and the source, provide a link to the Creative Commons license, and indicate if changes were made.

\section{References}

Aust HP (2014) The UN human rights due diligence policy: an effective mechanism against complicity of peacekeeping forces? J Conflict Secur Law 20(1):61-73

Blokker NM, Schrijver NJ (eds) (2014) Immunity of international organizations (special issue). Int Org Law Rev 10(2):255-619

Krieger H (2015) Addressing the accountability gap in peacekeeping: law-making by domestic courts as a way to avoid UN reform? Neth Int Law Rev. doi:10.1007/s40802-015-0032-z

Nederlands Instituut voor Oorlogsdocumentatie (2002) Srebrenica, een 'veilig' gebied: reconstructie, achtergronden, gevolgen en analyses van de val van een Safe Area. Boom, Amsterdam

Palchetti P (2015) Attributing the conduct of Dutchbat in Srebrenica: the 2014 judgment of the District Court in the Mothers of Srebrenica case. Neth Int Law Rev. doi:10.1007/s40802-015-0027-9

Schmalenbach K (2015) Preserving the Gordian knot: UN legal accountability in the aftermath of Srebrenica. Neth Int Law Rev. doi:10.1007/s40802-015-0028-8

Trapp KN (2015) Of dissonance and silence; state responsibility in the Bosnia Genocide case. Neth Int Law Rev. doi:10.1007/s40802-015-0031-0

Van den Herik L (2015) Accountability through fact-finding: appraising inquiry in the context of Srebrenica. Neth Int Law Rev. doi:10.1007/s40802-015-0035-9

Van der Wilt H (2015) Srebrenica: on joint criminal enterprise, aiding and abetting and command responsibility. Neth Int Law Rev. doi:10.1007/s40802-015-0036-8

Voorhoeve J (2015) Veilige gebieden. Falen en slagen bij het beschermen van burgers in oorlogstijd. Atlas Contact, Amsterdam/Antwerp

Zyberi G (ed) (2013) An institutional approach to the responsibility to protect. Cambridge University Press, Cambridge

33 Schmalenbach (2015). 